\title{
Architecture of the Information System of Evaluating of the Land Resources Based on Processing of Spatial Data
}

\author{
Yurii A. Maglinets, \\ Ksenia V. Raevich and Gennady M. Tsibulskii* \\ Siberian Federal University \\ Russia, 660041, Krasnoyarsk, Svobodny 79
}

Received 24.12.2016, received in revised form 18.09.2017, accepted 20.11.2017

The architecture and the main characteristics of an information system are presented in article, they allow to solve a complex of the problems connected with estimation of a condition of agricultural lands on the basis of processing of spatial data. The system is based on the ontology of estimation of agroeconomic capacity of lands developed by authors.

Keywords: architecture of the information system, ontology of lands evaluation, remote sensing of Earth, agricultural lands, multicriteria evaluation of lands, spatial data.

Citation: Maglinets Yu.A., Raevich K.V., Tsibulskii G.M. Architecture of the information system of evaluating of the land resources based on processing of spatial data, J. Sib. Fed. Univ. Eng. technol., 2018, 11(1), 52-60. DOI: 10.17516/1999-494X0008 .

\section{Архитектура информационной системы}

\author{
оценки земельных ресурсов
}

на основе обработки пространственных данных

\author{
Ю.А. Маглинец, К.В. Раевич, Г.М. Цибульский \\ Сибирский федеральный университет \\ Россия, 660041, Красноярск, пр. Свободный, 79
}

\footnotetext{
В статье представлена архитектура и основные характеристики информационной системы, позволяющейрешатькомплексзадач, связанныхсочениваниемсостояниясельскохозяйственных угодийна основе обработки пространственных данных. Система базируется на разработанной авторами онтологии оценивания агроэкономического потенщиила земель.
}

(c) Siberian Federal University. All rights reserved

* Corresponding author E-mail address: ymaglinets@sfu-kras.ru,kshatrova@sfu-kras.ru 
Ключевые слова: архитектура информационной системы, онтология оценки земель, дистанционное зондирование Земли, пахотные земли, мультикритериальная оценка земель, пространственные данные.

\section{Introduction}

Land evaluation problem is solved in a wide range of practical applications. It affects the areas of human knowledge such as: ecology, economics, landscape science, soil science, crop and others. Review of the literature [1-8] showed high variability of solved problems in this context.

All existing tasks can be divided into two classes: static and dynamic evaluation. In the first case, the goal is to provide an integrated assessment of the current state of the land based on field measurements, knowledge of the history of its use, the state of its infrastructure and other relevant factors. Depending on the peculiarities of the task, the result of solving it may be assessment of the market or cadastral value, assigning quality score, rank in the system of comparative land analysis, etc. In the second case, the goal is to obtain private rapid assessment of the vegetative cover condition or the progress of agro-technical measures. This need arises in the monitoring tasks, the results are used to make management decisions, monitor the effectiveness of measures, budget spending, prediction of crop yields, generation of reports, etc.

Agricultural lands as the object of the study are characterized as a complex, multi-factor object. Their condition depends on climatic factors, the characteristics of the soil and vegetative cover, infrastructure peculiarities, geospatial characteristics of the analyzed sections of the earth's surface, etc. In the scientific literature there are a lot of overlapping systems of land parameters classification essential for evaluation. Considered, reliable estimates are based on the knowledge of experts in various fields: geobotany, economy, ecology, agriculture, resulting in a complicated and costly process of decision-making support. In order to outline the experts' knowledge and present it in a formalized manner available for use, it is necessary to use the methods and means of getting, presenting, structuring and using the knowledge. The basis for a consistent presentation of information received from different sources is an ontological approach. In this paper, we consider the geoinformation system of evaluation based on the system of ordering the knowledge of agricultural lands as the object of evaluation in the form of ontology which is invariant to the specific task.

\section{The model of an agrarian land resource}

Approaches to the construction of the ontology of evaluation of the land agro-economic potential have been developed in the works $[8,9,10]$. When building the ontology, the object of evaluation is understood as a spatially localized area of the earth's surface, which is involved in the agricultural production.

The ontology of evaluation is assumed by the four parameters

$$
O=<K, T, E, M>
$$

where $\mathrm{K}$ - is the taxonomy of land indicators, $\mathrm{T}$ - is a set of tasks being solved, $\mathrm{E}$ - is a set of metrics of indicators' estimation, $\mathrm{M}$ - is a set of primary metrics that allow to calculate the numerical value of the indicator in physical terms. 
The considered ontological model is based on the taxonomy $\mathrm{K}$ for evaluation of the agro-economic potential of lands given in Formula 2.

$$
K=<N, R>
$$

where $\mathrm{N}=\left\{\mathrm{n}_{\mathrm{i}}\right\}$ is a set of taxonomic classes - indicators of the assessed object, $\mathrm{R} \subset\{\mathrm{N} \times \mathrm{N}\}$ is the relation of the $\mathrm{N}$ order. The taxonomic tree root vertex corresponds to the desired integral characteristics of the object being assessed. In this version of taxonomy, the classification upper level sets six classes of indicators comprehensively describing the subject area.

Further, the descending construction of the taxonomy forms subtrees of different depths. Their verteces can be classified as follows: abstract verteces; attributed verteces.

To measure the natural parameters the ontology uses primary metrics given in (1) by the variety M. A specific metric mi $\in \mathrm{M}$ is a functional property put in correspondence to the relative node $\mathrm{nj} \in \mathrm{N}$, for which the interval of acceptable values and the measurement unit are determined.

For the signification based on measurements the ontology has a lot of metrics of evaluation $\mathrm{E}_{\mathrm{m}} \subset \mathrm{E}$, also set in the form of functional properties ej $\in$ Em compared to the node nj. For ej a functional relationship is determined which allows to calculate a numerical estimate of the property $n_{i}$ based on the value of the primary metric mj. The resulting combination $<\mathrm{n}_{\mathrm{i}}, \mathrm{m}_{\mathrm{j}}, \mathrm{e}_{\mathrm{j}}>\in \mathrm{N} \times \mathrm{M} \times \mathrm{E}_{\mathrm{m}}$ sets the instance of the corresponding ternary relation that uniquely identifies the attribution rules on the basis of the measurement.

For attribution on the basis of aggregation the ontology has a lot of evaluation metrics $\mathrm{E}_{\mathrm{a}} \subset \mathrm{E}$; $\mathrm{E}=\mathrm{E}_{\mathrm{m}} \cup \mathrm{E}_{\mathrm{a}}$; $\mathrm{E}_{\mathrm{m}} \cap \mathrm{E}_{\mathrm{a}}=\emptyset$. The specific metric $\mathrm{e}_{\mathrm{i}}$ is described by:

1) functional property relating $e_{i}$ to the evaluated property $n_{j}$;

2) weighted tree of aggregation with depth 1 with the root vertex $e_{i}$ and a set of vertices - evaluation metrics that are incident to the elements of the subset $\mathrm{X}$ of the set of attributed verteces $\mathrm{Y}$ of the top $n_{j}$ in the taxonomy of evaluation. The weights of the tree arc characterize the degree of influence of assessment of the relevant subsidiary top on the evaluation of the root vertex;

3) calculation procedure that allows to calculate the evaluation $e_{i}$ for the property nj on the basis of aggregation of evaluation values for the nodes $\mathrm{x}_{1} \in \mathrm{X}$ and weights of the aggregation tree arcs.

The ontology components considered above give basis for constructing the evaluation tasks solution system. The tasks being solved $t_{j}$ determine the set $\mathrm{T}$ of the tasks given in the taxonomy. The structure of describing a certain task $t_{i}$ is determined as follows (Formula 3 ):

$$
t_{i}=<K_{i}, E_{i}, M_{i}>
$$

where $K_{i} \subset K$ is a subgraph of the taxonomy corresponding to the task being solved, $M_{i} \subset M$ is a set of primary metrics relevant to the task of evaluation, $\mathrm{E}_{\mathrm{i}}-$ is a set of evaluation metrics.

\section{System architecture}

All three categories of users - experts, GIS-specialists, and managers (decision-makers, DMs) are engaged in operation of the system.

Experts' role in the system is as follows:

1) Initial input of data, ensuring the system integrity, ontology development and verification;

2) Formation of task solution schemes. 
DM area of competence - stating the evaluation task and analysis of task solution results.

The task of a GIS-specialist includes automated selection and processing of data and making it easily comprehensible by a DM.

Let's review the functions of the main system components (Fig. 1).

Knowledge database. The main units used for information storage in a database are ontology versions and task solution schemes. The knowledge database management system performs the functions of ensuring integrity of storage units, management of versions and revisions, editing and copying of components. It also supports the mechanists of creating and editing of tree lists and frames that correspond to tree nodes with account of node specialization as described above.

Spatial database (SD) includes vector layers that contain spatial coordinates of analyzed polygons representing agricultural lands, raster layers that represent the results of GPS survey of analyzed area, as well as the necessary attributive data associated with polygons. SD is related with the knowledge database, each attribute has a link to the relevant taxonomic vertices of agricultural land parameters.

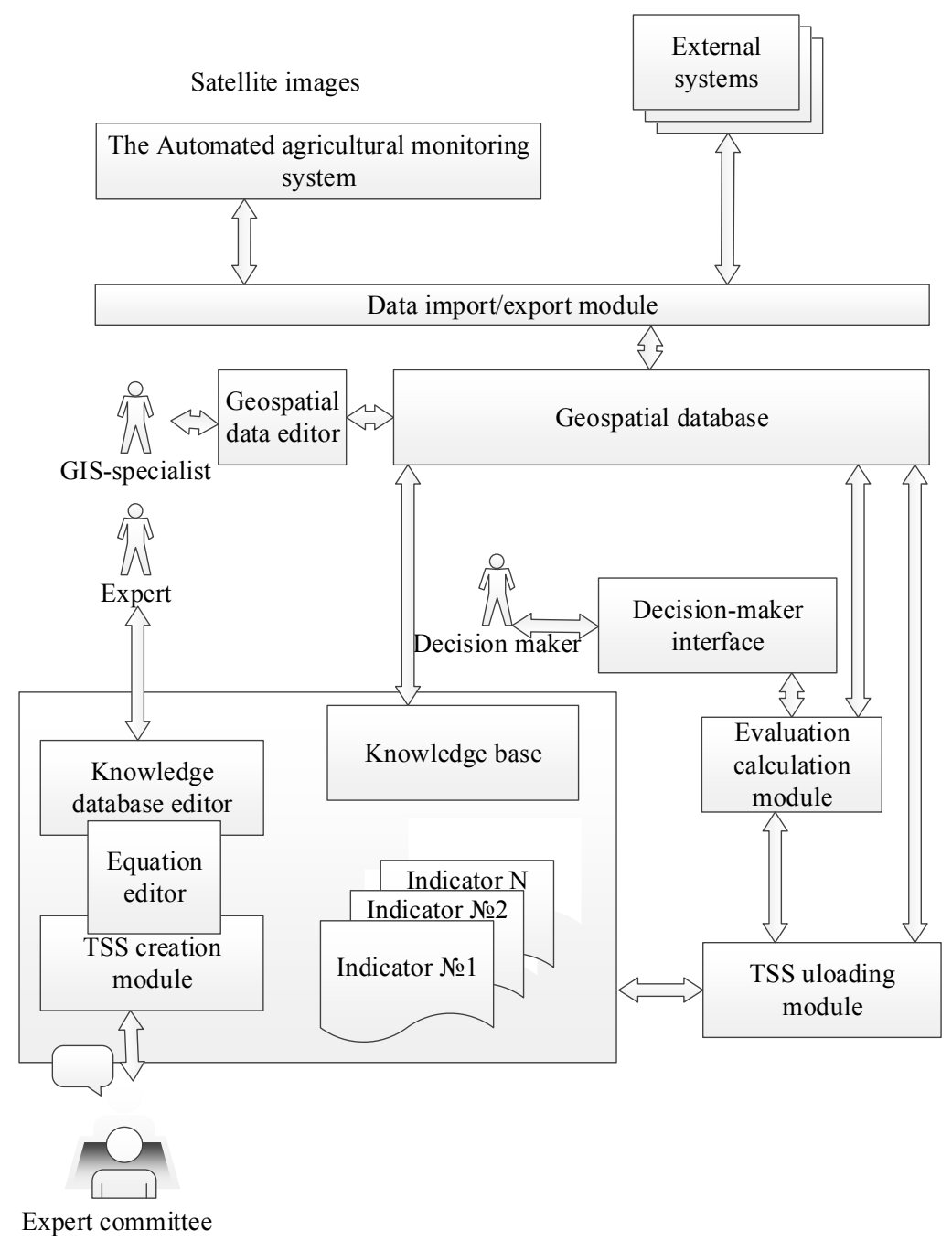

Fig. 1. The system architecture 
Knowledge database editor provides an expert in charge of ontology tools for creating and editing a taxonomic version. A user can associate each taxonomic vertex with primary metrics and evaluation metrics, as well as assign computation procedures required for calculations.

Task solution scheme editor (TSS editor) allows an expert in charge of task representation to create and maintain TSP within a specified ontology version, as well as perform migration of the task description into revised ontology versions. TSP customization includes a dialogue procedure of creating a subtree of initial taxonomy; each TSP vertex is created as a copy of the relevant initial taxonomy vertex and can be edited, for instance, to specify computation procedures. TSP editor functions also include arrangement of liaison for generation and approval of expert evaluations. Such liaison is described below.

A procedure of describing computation correlations for evaluation metrics arises when creating and modifying ontologies and TSPs. The procedure is based on using formula editor that is used as a procedure called by knowledge database editor and TSP editor. Beside basic mathematical operations, the formula generator provides a feature of generating tabulated functions.

Geospatial data (GSD) editor serves for preparation and operations with geospatial description of the copy of the task being solved.

When creating a blank copy of the task being solved, TSP unloading module generates a vector layer template with a predefined set of attributes assigned within the task solution scheme that is placed in the GSD database. Then the layer is filled with data on spatial coordinates of the object being evaluated, a vector projection of data onto the analyzed area is generated that contains an array of objects being evaluated in the form of geospatial objects.

Data import-export module interrelates with an automated agricultural monitoring system [11] and other external systems that allows obtaining data based on processing and analysis of aerospace image, ground measurements, data from meteostations and other sources, as well as exporting data into outside systems.

Calculation of intermediary and final evaluations is done by evaluation calculation module. Evaluation visualization is performed via DM interface that allows forming spatial data representation in the form of vector layers with calculated attributes, as well as displaying data in tabular form or by business graphics means.

\section{Task Solution Scheme of the lands assessment}

The ontology discussed above acts as reference data required to solve the land evaluation task. Forming and maintaining the ontology in a consistent state can be regarded as a preliminary stage providing operation to solve this task. Factographic information is represented by a set of vector and raster layers in shape-format. The goal of evaluation is formed in the dialogue with the end user.

At the first stage, it is necessary to define a task. The task is defined in the dialogue with the end user. As an example, you can specify the task as "To assess the potential effectiveness of the land use for the production of grain crops"; "To carry out the ranking of fallow lands from the standpoint of expediency of their remediation". The purpose is expanded by the indication of geographical coordinates of the research object, the layer of agricultural lands to be assessed and additional attribute information is loaded. 
At the second stage the calculating procedure of the assessment is developed. In accordance with the basic procedure, assessment of agricultural lands equals the linear combination of the values of indicators being evaluated in accordance with Formula.

$$
\text { O(agriculturallands })=\sum_{i=1}^{n} k_{i} * f_{i}(\text { agriculturallands })
$$

where $f_{i}$ is the value of the i-th indicator, $k_{i}$ is the value of weight coefficient of this indicator, $n$ is the amount of indicators used in the assessment.

The purpose of this stage is to develop the sequence of indicators $\mathrm{F}=\{\mathrm{fi}\}$, relevant to the goal of evaluation, as well as to determine the calculation method for each $f i \in \mathrm{F}$. The stage is carried out in the dialogue between the user-expert and the system. Then, the indicators measurement scales (primary metrics) are determined, the metrics of the measurement result assessment is set and the calculating procedure for the conversion of the primary metrics to the metrics of evaluation is determined. The scale of measurement of the primary metrics is determined by the physical parameters of the measured value. For the metrics of evaluation scale intervals are used.

Results of the task solution will be shown to the person who making decisions in the form of the atlas of agricultural lands (Fig. 2).

At the third stage, the expert committee is formed. The committee members are selected out of the most authoritative experts in the subject area. The elements of the "snowball" method were used to create the expert committee for the development of scoring. The coefficient of concordance was used to measure the closeness of the connection between groups of factors being ranked.

At the fourth stage, the system of indicators formed earlier was ranked using the methods of expert estimates. In order to collect the opinions of experts the author's questionnaire was developed.

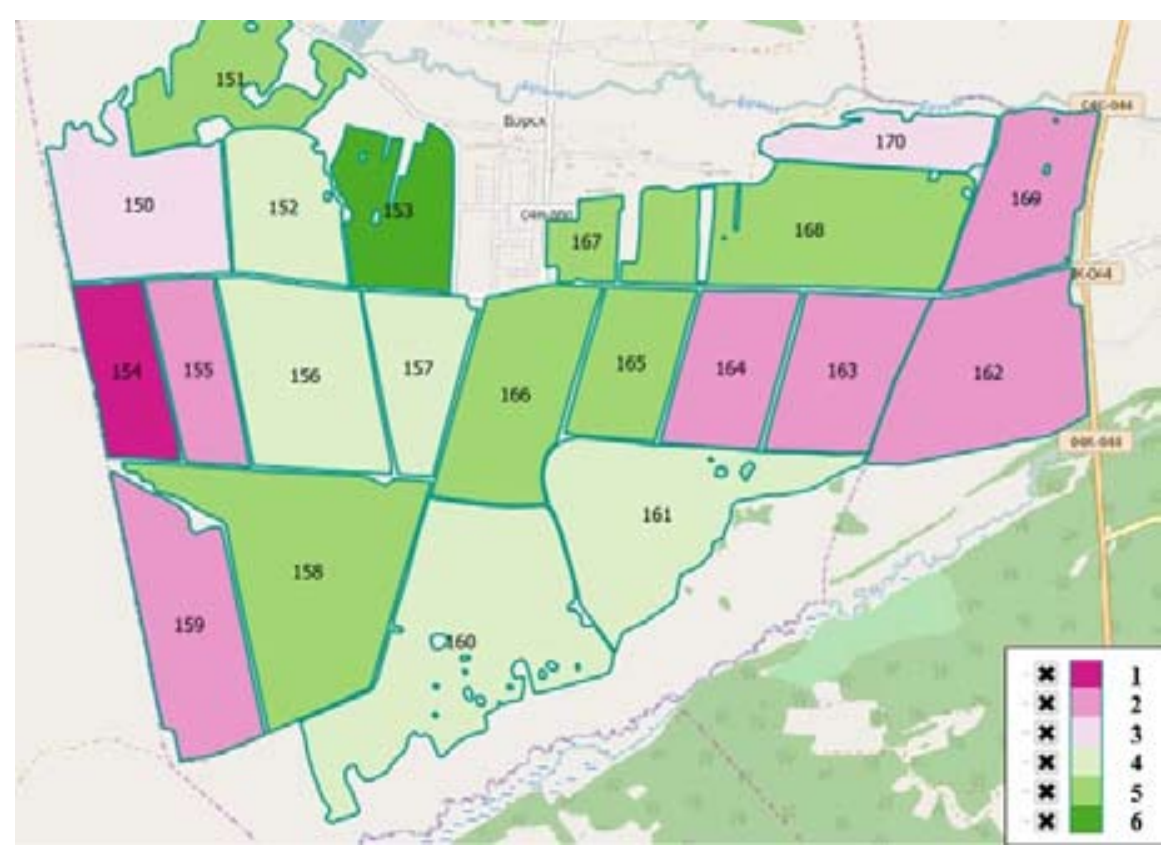

Fig. 2. The Sample of the Atlas of the lands assessment results 
The expert survey is carried out in one round by a one-time filling out of the questionnaire. Experts are invited to determine the importance of specific factors.

The experts assess the significance of versions using a ranking procedure.

At the fifth stage of the method, the consistency of experts' opinions is assessed in accordance with Formula 5.

$$
W=\frac{S}{\frac{1}{12} m^{2}\left(n^{3}-n\right)} .
$$

The importance of the concordance coefficient is assessed by Pearson criterion according to Formula 6.

$$
X^{2}=\frac{S}{\frac{1}{12} m n(n+1)} .
$$

At the sixth stage, the primary metrics and metrics of evaluation are calculated and the results of calculation of the primary metrics' fields are collected. These results are presented to the experts for evaluation according to the binary scale "AcceptablelUnacceptable". If the percentage of negative evaluations is more than $10 \%$, then the return to the 4th stage is done for re-adjustment of the weight coefficients.

At the seventh stage, the scheme for solving the task is generated and saved to form the version of the knowledge base.

The eighth and final stage includes the necessary calculations; the solution of the task is generated in the form of an atlas of agricultural lands, as well as in the form of tables and diagrams.

The atlas shows the land subject to evaluation. Colour codes denote the value in points that increases as the final evaluation increases.

\section{Conclusion}

At the present moment a working prototype of the system has been developed. The software tool for the system is free software Protégé 3.5, Quantum GIS 1.8, as well as author's software written in language $\mathrm{C} \#$ implemented on the basis of the programming package Microsoft Visual Studio 2013. This system is based on a constantly updated and adjustable knowledge base about agricultural lands as complex, multi-factor objects. The mechanism to specify and expand the knowledge base is provided through the version control system. The developed system complements the agricultural monitoring automated system previously developed by the team, allowing to generate and store a library of schemes for solving agricultural lands evaluation tasks, including the ability of dynamical monitoring of their change during the vegetation season and support of management decision-making. The schemes for solving the tasks are generated on the basis of expert assessments and, after checkout on the significant amount of experimental data; they can be used as an objective tool by scaling to other areas that have a similar set of climatic conditions. Thus, the four-level view of information is supported: 1) the system of knowledge describing the subject area of agricultural lands assessment; 2) the scheme of the task describing the specific formulation of the task and containing declarative and procedural means to solve it; 3) the copy of the task to be solved, which is localized in the field; 4) the solution of the task localized in time.

$$
-58-
$$


The system presented in the work is currently being pilot tested on solving the tasks of agricultural lands evaluation in the Sukhobuzimsky District of the Krasnoyarsk Territory on behalf of the district administration and economic entities.

\section{References}

[1] Мартынов К.П. Оценка земель сельскохозяйственного назначения. Электронный журнал МГУ имени Н.П. Огарева, 2012, 4(18) [Martynov K.P. Evaluation of agricultural lands. Electronic journal of Mordovian State University named after N.P. Ogarev, 2012, 4(18) (in Russian)].

[2] Терехов А.Г., Витковская И.С., Батырбаева М.Ж., Спивак Л.Ф. Принципы агроландшафтного районирования пахотных земель Северного Казахстана по данным LANDSAT и MODIS. Современные проблемы дистанционного зондирования Земли из космоса, 2010, 7(3), 292-304 [Terekhov A.G., Vitkovskaya I.S., Bartaleva M.Zh., Spivak L.F. Principles of agricultural and landscape zoning of crop lands in Northern Kazakhstan according to the data of LANDSAT and MODIS. Modern challenges of remote probing of the Earth from space, 2010, 7(3), 292-304 (in Russian)].

[3] Анохин Е.И. Понятие, принципы и методы оценки земель сельскохозяйственного назначения. Проблемы современной экономики, 2010, 3(35) [Anokhin E.I. Understanding, principles and methods of agricultural lands assessment. Challenges of modern economics, 2010, 3(35) (in Russian)].

[4] Иванов А.Л., Савин И.Ю., Егоров А.В. Методология оценки ресурсного потенциала земель России для сельскохозяйственного производства (на примере хмеля). Бюллетень Почвенного института им. В.В. Докучаева, 2014, 73, 19-53 [Ivanov A.L., Savin I.Yu., Egorov A.V. Methods of evaluation of the resource potential of lands in Russia for agricultural production (on the example of hop). Bulletin of V.V. Dokuchaev's Soil Institute, 2014, 73, 19-53 (in Russian)].

[5] Стадник А.П., Лукіша В.В. Формування критеріїв та показників для еколого-економічного оцінювання сільського сподарського землекористування. Агроекологічний журнал, 2011, 3, 5-12 [Stadnik A.P., Lukisha V.V. Formation of criteria and indicators for environmental and economic assessment of agricultural land use. Agroenvironmental magazine, 2011, 3, 5-12 (in Ukrainian)].

[6] Гуреева О.В. Особенности земель сельскохозяйственного назначения как объекта оценки. Вестник Саратовского государственного социально-экономического университета, 2008, 4, 78-81 [Gureeva O.V. Peculiarities of agricultural lands as the object of evaluation. Newsletter of Saratov State Socio-economic Univeristy, 2008, 4, 78-81 (in Russian)].

[7] Шатрова К.В., Маглинец Ю.А., Аникьева М.А., Герасимчук М.Г. Концептуальная модель предметной области оценивания земель сельскохозяйственного назначения на основе привлечения геопространственной информации. Сборник тезисов Одиннадиатой открытой Всероссийской конференции «Современные проблемы дистанционного зондирования Земли из космоса», Москва, ИКИ РАН, 11-15 ноября 2013, 87 [Shatrova K.V., Maglinets Yu.A., Anikyeva M.A., Gerasimchuk M.G. A conceptual model of the subject area of agricultural lands assessment on the basis of geospatial information. Eleventh Open All-Russian Conference "Modern challenges of remote probing of the Earth from space”, Moscow, Space Research Institute of RAS, November 11-15, 2013, 87 (in Russian)]. 
[8] Кузнецов К.А., Серебряков В.А., Теймуразов К.Б., Устинова Е.С., Малахов Д.А. Онтологическое моделирование и публикация данных об особо охраняемых природных территориях. Труды 14-й Всероссийской научной конференции «Электронные библиотеки: перспективные методы и технологии, электронные коллекиии»-RCDL-2012, ПереславльЗалесский, Россия, 15-18 октября 2012 [Kuznetsov K.A., Serebriakov V.A., Teymurazov K.B., Ustinova E.S., Malakhov D.A. Ontological modelling and publishing of the data regarding Specially Protected Natural Territories. Works of the 14th All-Russian Scientific Conference "Electronic libraries: prospective methods and technologies, electronic collections" - RCDL-2012, Pereslavl-Zalessky, Russia, October 15-18, 2012 (in Russian)].

[9] Маглинец Ю.А., Мальцев Е.А., Брежнев Р.В., Соснин А.С., Цибульский Г.М., Шатрова К.В. Программно-технологическая инфраструктура представления и обработки геопространственной информации муниципального района. Современные проблемы дистанционного зондирования Земли из космоса, 2012, 9(3), 316-323 [Maglinets Yu.A., Maltsev E.A., Brezhnev R.V., Sosnin A.S., Tsibulskii G.M., Shatrova K.V. Program-technological infrastructure of geospatial information representation and processing of municipal region. Modern challenges of remote probing of the Earth from space, 2012, 9(3), 316-323 (in Russian)].

[10] Раевич К.В., Маглинец Ю.А., Зеньков И.В. Разработка системы поддержки принятия решений в управлении использованием земледельческого сектора агропромышленного комплекса в регионах Сибири. Вестник Иркутского государственного технического университета, 2016, 6(113), 89-98 [Raevich K.V., Maglinets Yu.A., Zenkov I.V. Development of the support system of management decision-making in the use of agricultural sector of agro-industrial complex in Siberian regions. Newsletter of Irkutsk state Technical University, 2016, 6(113), 89-98 (in Russian)].

[11] Perfil'ev S.E., Maglinets Y.A., Tsibul'skii G.M., Mal'tsev E.A., Latyntsev A.A., Shatrova K.V. Intelligent geoinformation technology for agroecological mapping. Pattern Recognition and Image Analysis, 2013, 23(4), 528-535. 